\title{
Agrocluster as an instrument of socio-economic policy for the development of the region (based on the Rostov Region data)
}

\author{
Tatiana Cherkasova ${ }^{1, *}$,Elena Zolochevskaya ${ }^{1}$, Evgenia Kondratenko $^{1}$, Anna Kritskaya ${ }^{1}$, \\ and Oleg Artyukhin ${ }^{1,2}$ \\ ${ }^{1}$ Russian Presidential Academy of National Economy and Public Administration, Pushkinskaya str., \\ 70/54, Rostov-on-Don, 344002, Russia \\ ${ }^{2}$ Don State Technical University, Gagarin Square, 1, Rostov-on-Don, 344003, Russia
}

\begin{abstract}
The purpose of the article is to identify additional opportunities for using agricultural clusters to stimulate the socio-economic development of agricultural territories and diagnose the constraining problems of modern clustering policy using the example of the Rostov region. The use of the cluster methodology made it possible to rethink the toolkit of the regional policy, considering not individual enterprises as an object of regulation, but integrated structures that can become regional "growth areas". The article describes some interesting findings. First, the cluster strategy made it possible to ensure sustainable growth rates of individual regions, which became the driver of the development of the leading world powers. Secondly, the Russian experience of cluster development made it possible to identify the competitive advantages and internal regional resources for development, increasing the competitiveness of the cluster structure partners. Increasing the competitiveness of business is of particular importance for the agro-oriented regions of Russia, since the agricultural sector is subject to greater natural risks. Thirdly, the positive impact of agricultural clusters on the socio-economic development of the Rostov region, including that over the Covid-19 pandemic period, is highlighted. Fourth, constraints have been identified that reduce the effectiveness of the cluster policy.
\end{abstract}

\section{Introduction}

Against the background of the depressive recovery of the Russian economy in 2017-2019, after the prolonged stagnation of 2010-2014, which was replaced by a new economic decline in 2015-2016, amid geopolitical risks and anti-Russian sanctions, the unpredictable risk associated with the Covid-19 pandemic had a negative impact on socio-economic problems of Russian development in general, and on the development of some regions in particular.

So, at the end of 2020, according to the Ministry of Economic Development, the reduction in Russia's GDP was 3.8\% [1].

\footnotetext{
*Corresponding author: tpch@mail.ru
} 
Undoubtedly, the Government of the Russian Federation reacted to the negative macrodynamics and curtailment of business activity during the period of self-isolation in the spring-summer of 2020 with two stages of support program packages totaling \$ 2.1 trillion. rubles. Specific measures include, in particular, six-month deferrals for all tax payments for small and medium-sized businesses, credit holidays for interest payments and interest-free loans for the payment of wages. Government support measures related to the introduction of a moratorium on the bankruptcy of small and medium-sized enterprises and the launch of special credit programs can also be considered effective. Now the 3rd and 4th stages of state support programs are being developed.

In 2020, the regions received an additional 300 billion rubles to compensate for lost income. Over 11 months, the volume of interbudgetary transfers increased by $60 \%$ (compared to the same period in the previous year). The measure made it possible to increase the expenses of entities by $14 \%$ in 11 months compared to 2019 , while their own revenues decreased by $4 \%$.

However, it should be recognized that regional economies have not been equally affected by the Covid-19 pandemic and have different internal resources and conditions for recovery, which requires the analysis of the problem at the intraregional level, taking into account the differentiation of regions by their specialization and general socio-economic level of development.

For example, the South of Russia is characterized by its own characteristics of economic development based on natural and climatic conditions, geographic features and geostrategic factors. Agricultural specialization has been entrenched in the South of Russia, which, on the one hand, solves the problems of food security of the country, and, on the other hand, makes it possible to ensure sustainable development due to positive export dynamics. However, the opportunities to succeed in this area are due not only to the starting natural, climatic and geographical conditions, but also to the technical and technological development and scientific and personnel potential of the southern regions, which ensure high competitiveness for agribusiness.

An important condition for increasing competitiveness is organizational and managerial forms of agribusiness, focused on reducing or compensating for costs associated with unpredictable and high natural risks in this area. As the world experience and domestic practice reveal, an important tool for the socio-economic policy of regional development is the cluster organization of business, whose advantages allow to minimize various risks and ensure the financial stability and competitiveness of enterprises and organizations comprising the cluster structure.

In this study, an agrocluster is understood as a geographically grouped set of economically proactive actors in the economic, innovation and educational spheres, integrated into a single organizational structure on the basis of agreements without losing legal independence, motivated to cooperation within the framework of agro-industrial production.

The main goal of the cluster policy is to create conditions for increasing the competitiveness of the domestic economy by stimulating integration associations within the same or related industries. The goal encompasses four basic tasks, to the solution of which the policy of agrarian clusterization is oriented:

- development and support of the formation of cluster structures in the field of regional specialization;

- formation of the cluster infrastructure in full;

- financial support for clustering processes from budgets of all levels and extra-budgetary sources under government guarantees;

- consulting support for investment projects aimed at increasing the competitiveness of the cluster's business partners. 
In this regard, it seems expedient to conduct additional research and determine the possibilities of agro-cluster tools in solving the problems of socio-economic development of regions with agricultural specialization in the context of the Covid-19 pandemic.

\section{Materials and Methods}

The information base for the study includes official statistics, which made it possible to assess the macrodynamics and features of regional development, highlight their successes and the problems encountered; analysis of foreign experience in clustering and expert assessments of the effective use of cluster tools to initiate economic growth in regions of different countries of the world.

The analysis of strategic documents governing the implementation of socio-economic policy in the country for the medium term, for the period 2018-2020, has been carried out. It concentrated on Decree of the President of the Russian Federation of May 7, 2018 No. 204 "On national goals and strategic objectives of the development of the Russian Federation for the period up to 2024" (hereinafter Decree No. 204) and the forecast of socio-economic development of the Russian Federation for the period up to 2024. Decree No. 204 sets the main national development goals and priority tasks, oriented to the implementation of staterun measures within the framework of socio-economic policy. Thus, the priorities of socioeconomic development for the period up to 2024 are focused on promoting the development of human capital and improving living standards. The solution of these tasks is possible provided that sustainable rates of economic growth are ensured by mobilizing the internal economic potential of the regions. Moreover, the main source of growth could only be investments and innovations in priority spheres and sectors of the economy.

The analyzed strategic documents of the regional level include: the "The Concept of Cluster Development of the Rostov region for 2015-2020", approved by the decree of the Rostov Region Government of 12.03.2015 No. 164 and "the Strategy for the Development of Priority Territorial Clusters of the Rostov Region for 2016-2020" (approved by the Government Rostov Region dated 16.02.2016, No. 104).

The choice of the Rostov region in southern Russia for analysis can be justified by agrarian specialization and the implementation of a cluster development strategy, with the emphasis on the agro-cluster.

\section{Results}

M. Porter, considered the founder of the clustering policy methodology, developed, within the framework of the theory of international competition and competitive advantages, the idea of clustering, according to which new integration associations have certain competitive advantages, "economies of scale" in particular, reducing transaction costs and increasing financial stability. M. Porter offered one of the first definitions of a cluster as a group of "geographically adjacent interconnected companies and related organizations of a certain field, characterized by common activities and complementary to each other" [2]. Despite the fact that the development of the cluster structures theory by M. Porter began in the 1990s its provisions and recommendations remain relevant today.

Later, the cluster theory was developed in the works of contemporary foreign authors [35] and some Russian scientists [6-7], who consider cluster policy from the standpoint of creating the necessary conditions by the authorities to form regional clusters in order to stimulate the accelerated development of territories.

California's Silicon Valley is considered a classic example of successful world practice in creating regional clusters and ensuring innovative economic growth on their basis. It is a 
gigantic cluster that has united representatives of venture capital, banking and financial institutions, leading research centers and about 100 thousand business structures into a single agglomeration structure [8].

A feature of the Japanese regional clustering is the configuration of the cluster organizational system. Its core is a large corporation, uniting many medium-sized and small firms. The competitive advantage of such a cluster structure is the ability of a large corporation to provide technological economies of scale. The state policy of Japanese regional clustering focuses on creating conditions for the interaction of large regional industrial enterprises with state research organizations and higher educational establishments. The Japanese carmaker Toyota should be mentioned as a worthy example of regional clustering policy. The automotive industry cluster is an integration association of more than 100 large supplier partners with more than 35,000 organizations - subcontractors, representatives of small and medium-sized businesses.

Researchers and experts on clustering policy identify the main motivational factors for the formation of cluster structure [9-10]:

- the emergence of new sources of specialized technologies and technical developments from the cluster partners;

- initiation of regional innovation processes related to the development and commercialization of innovative products;

- increasing the investment attractiveness of regional business structures in the form of a cluster;

- creation of new jobs;

- training of highly qualified specialists on order and for specific jobs;

- import substitution of the main types of products;

- bringing regional business to national and foreign sales markets.

The Russian policy of clustering dates back to 2010. The beginning of its implementation can be considered the formation of a non-profit association - the Association of Technoparks in the field of high technologies. Four years later, it was transformed into the Association of Organizations for Assistance to the Development of Clusters and Technoparks, whose main task was to provide institutional support to the state program to create national technoparks, and later to promote their development and the formation of cluster structures in priority sectors and spheres of the Russian economy. The basis for the formation of the Association was a number of innovative and scientific organizations, including St. Petersburg Technopark, Ural University Complex, Ankudinovka IT Park, Zhigulevskaya Valley Innovation Center, Kuzbass Technopark, Sarov Technopark, Technopark of the Novosibirsk Academic City, Mordovia Technopark and a number of others.

According to the analytical information of the Association, 38 industrial clusters from 28 regions, including four interregional ones, operated in Russia in 2018. Large industrial enterprises made up the core of the cluster. As of 2020, the register of industrial clusters of the Ministry of Industry and Trade of Russia includes 44 successful clusters from 33 regions, which managed to attract investments in the amount of 21,792 million rubles, of which about 16,000 million rubles were extra-budgetary investments. As the analytical review of the Association notes, "industrial clusters from year to year continue to be the growth driver in the real sector of the Russian economy. In particular, labor productivity on average for industrial clusters is $30 \%$ higher than the average for the manufacturing industry in Russia, and amounts to 4.2 million rubles per person" [11]. The register of clusters of the Ministry of Industry and Trade of Russia includes two clusters of the Rostov region, one is the Volgodonsk cluster of nuclear engineering, the second is an industrial cluster of agricultural engineering.

In this regard, we can state the fact that the authorities of the Rostov region have already begun to implement the policy of regional clustering, following the all-Russian vector of state 
regulation. To date, a legal basis for the implementation of the cluster policy has been formed and separate strategic documents have been adopted. Of particular note is the creation and successful implementation of the Concept of Cluster Development of the Rostov Region for 2015-2020 (approved by the decree of the Rostov Region Government of 12.03.2015 No. 164) and the Strategy for the Development of Priority Territorial Clusters of the Rostov Region for 2016 - 2020 (approved by the Decree of the Rostov Region Government No. 104 of 16.02.2016). The strategy identifies six priority territorial clusters, the creation of which is planned within five years (Figure 1).

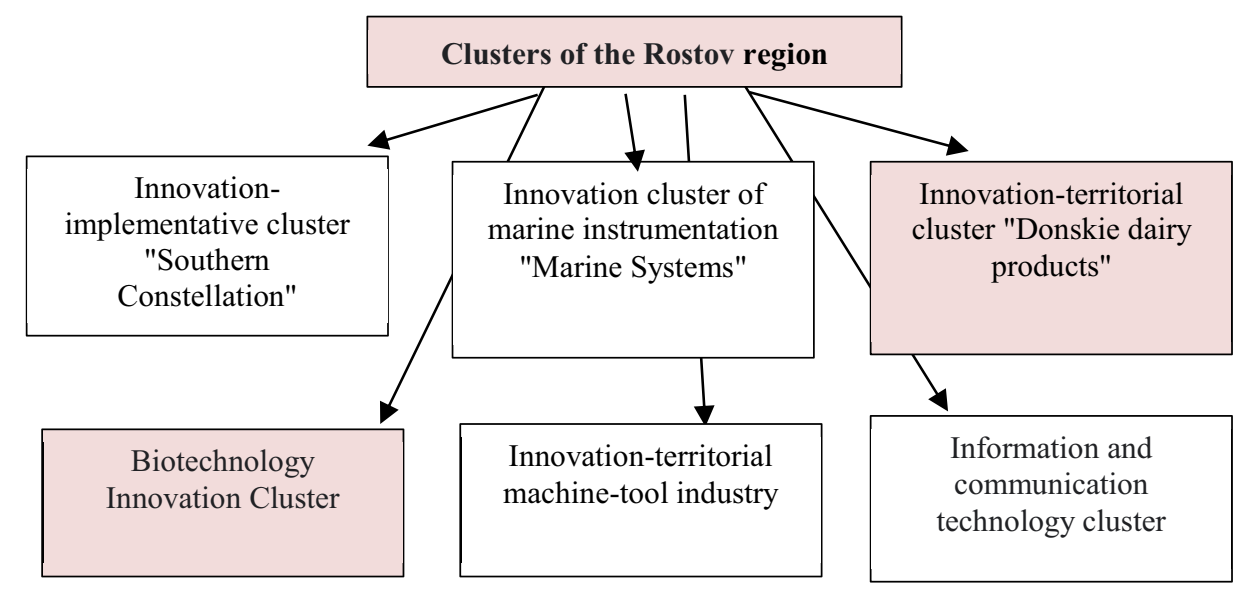

Fig. 1. Cluster structures created in the Rostov region.

The key principle of the designed clusters structure is the integration of specialized business structures and regional financial institutions or municipal territory around research institutes and higher professional education establishments, which become the initiator of innovative growth. Among the agricultural clusters of the Rostov region, of particular interest are three cluster structures, which resulted from the targeted policy of 2015-2020. [12]:

1. Regional biotechnological cluster, whose purpose is to organize effective production of starch products, high-protein feed and deep processing of corn, solving problems of import substitution. The backbone enterprise of the regional cluster is LLC Amilko, located in the Millerovsky district.

2. Agrocluster "Donskie dairy products" for the production and processing of dairy products in the Rostov region, formed by six large milk processing enterprises in the region. The main goal of the regional cluster is to provide import substitution of milk in the region.

3. The innovative agro-industrial cluster "Donskoye Myaso" is focused on the development of beef and mutton production at existing farms in the eastern territories of the Rostov region. Within the framework of created structure, a full cycle of meat production and processing is being implemented, starting with the production of pastures and feed, breeding and breeding activities and ending with the processing and sale of finished meat products. Simultaneously, an integration and cooperative chain is being formed which allows partner organizations to solve the issues of training specialists, obtaining new technical and technological, infrastructural, consulting and social solutions.

The accumulated positive experience and practices within the framework of cluster policies are being transferred into other regional agricultural spheres, allowing to strengthen their competitiveness, provide food not only for the region and the country, but also to master foreign markets, ensuring the growth of the regional economy and creating new jobs.

The efficiency of this policy is demonstrated by the data of regional statistics based on the results of the 1 st quarter of 2020. The agrosphere did not reduce production volumes 
despite quarantine measures and the Covid-19 pandemic, remaining at the same level. Thus, the regional production of food products in the first quarter of 2020 showed an increase of $3.5 \%$, while the production of beverages for the same period increased by $1 / 3$. No less significant increase in the volume of shipped products was shown by food processing enterprises, which amounted to $21 \%$ compared to the previous year.

It should be noted that there remain some unsolved problems within the framework of creating agricultural clusters which have to be tackled by the regional government in the medium term.

\section{Discussion}

World experience and domestic practice show that agricultural clusters are an effective tool for the socio-economic development of agricultural regions. The main advantages of the agrocluster making it an instrument of regional policy encompass [13-14]:

- common business interests of the cluster partners;

- financial stability due to the interdependence of production plans and coordination of actions in the resource market and finished product markets;

- innovative and technological character of production due to the inclusion of universities and research institutes in the cluster structure, ensuring the growth of competitiveness;

- synergistic effect from the integration of internal resources and competitive advantages of the region.

The structure of the agro-cluster, which allows using the synergistic effect and increasing the competitiveness of the national agro-sphere, is shown in Figure 2.

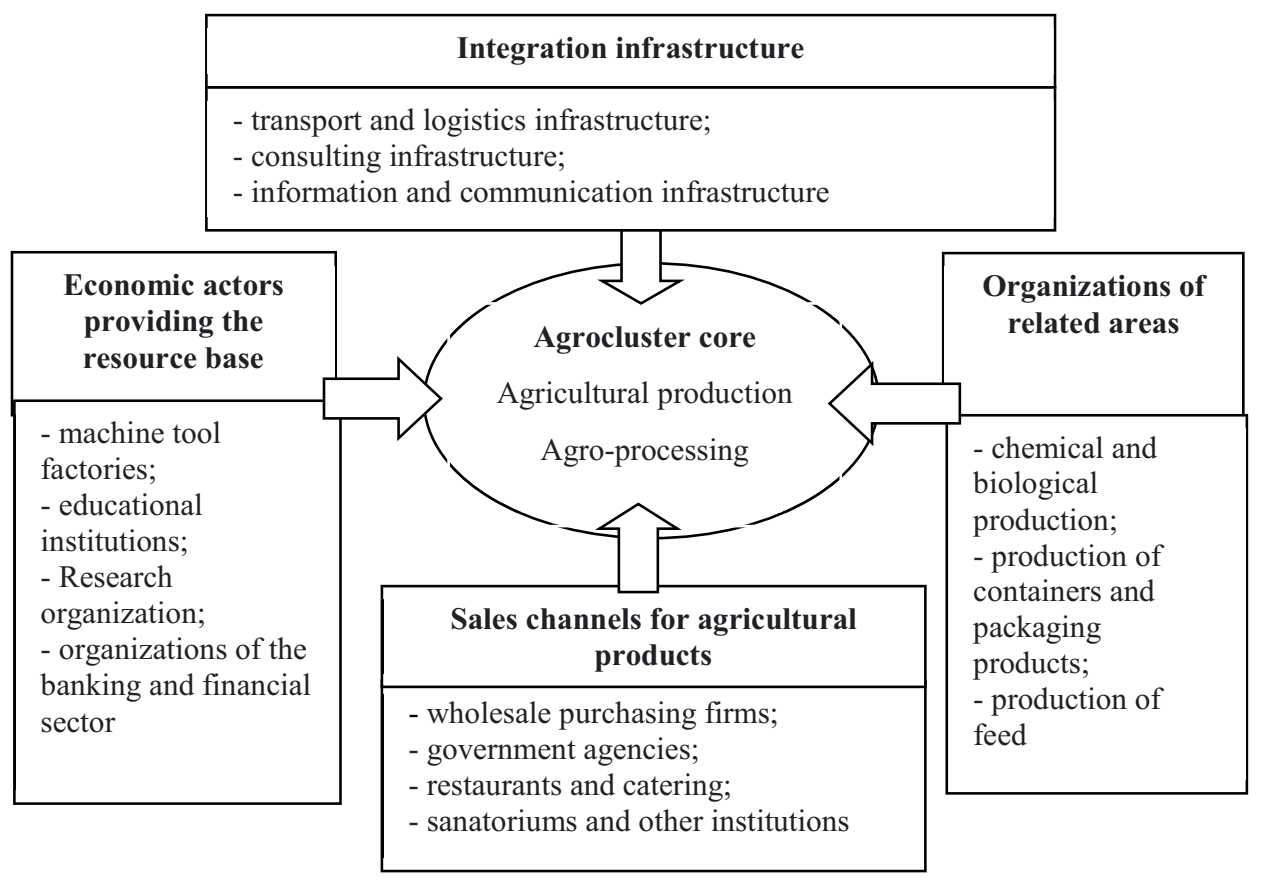

Fig. 2. The structure of the agrocluster [15].

Today, for the Rostov region, the most promising directions from the viewpoint of the agricultural cluster development can be the four presented in Table 1. 
Table 1. Priority areas for the formation and development of agricultural clusters in the Rostov region.

\begin{tabular}{|c|c|c|c|}
\hline $\begin{array}{l}\text { Field of } \\
\text { activity }\end{array}$ & Limiters & Constraints & $\begin{array}{c}\text { Potential vector of } \\
\text { development }\end{array}$ \\
\hline $\begin{array}{l}\text { Dairy } \\
\text { production }\end{array}$ & $\begin{array}{l}\text { Disunity and different } \\
\text { quality of the raw } \\
\text { material base; } \\
\text { Low } \\
\text { manufacturability of } \\
\text { production; } \\
\text { Underdevelopment } \\
\text { of the sales sphere }\end{array}$ & $\begin{array}{l}\text { Underdevelopment of } \\
\text { vertical and horizontal } \\
\text { integration and } \\
\text { cooperation ties between } \\
\text { commodity producers; } \\
\text { outdated technological } \\
\text { base; } \\
\text { Underdevelopment of } \\
\text { the brand; } \\
\text { Low competitiveness in } \\
\text { the trade area. }\end{array}$ & $\begin{array}{l}\text { Restoration of the } \\
\text { existing large dairy } \\
\text { production }\end{array}$ \\
\hline $\begin{array}{l}\text { Meat } \\
\text { production } \\
\text { and } \\
\text { processing }\end{array}$ & $\begin{array}{l}\text { Disunity and different } \\
\text { quality of the raw } \\
\text { material base; } \\
\text { Lack of integration } \\
\text { infrastructure }\end{array}$ & $\begin{array}{l}\text { Underdevelopment of } \\
\text { vertical and horizontal } \\
\text { integration and } \\
\text { cooperation ties between } \\
\text { commodity producers; } \\
\text { Outdated technological } \\
\text { base; } \\
\text { lack of the necessary } \\
\text { domestic feed base; } \\
\text { Physical and moral } \\
\text { deterioration of the } \\
\text { means of production; } \\
\text { Lack of developed } \\
\text { infrastructure }\end{array}$ & $\begin{array}{l}\text { Creation of selection and } \\
\text { breeding farms for } \\
\text { breeding cattle; } \\
\text { Formation of } \\
\text { prerequisites for the } \\
\text { integration of pig farms; } \\
\text { Development of farms } \\
\text { for the production of } \\
\text { eco-feed and } \\
\text { development of pastures; } \\
\text { Reconstruction of } \\
\text { industrial processing } \\
\text { enterprises }\end{array}$ \\
\hline $\begin{array}{l}\text { Production } \\
\text { of } \\
\text { vegetables } \\
\text { and fruits, } \\
\text { their } \\
\text { processing } \\
\text { and } \\
\text { conservation }\end{array}$ & $\begin{array}{l}\text { Low-tech production; } \\
\text { Lack of developed } \\
\text { sales sphere }\end{array}$ & $\begin{array}{l}\text { Lower competitiveness } \\
\text { in comparison with the } \\
\text { Krasnodar commodity } \\
\text { producers; } \\
\text { Lack of a developed } \\
\text { integration infrastructure }\end{array}$ & $\begin{array}{l}\text { Reconstruction of fruit } \\
\text { and vegetable processing } \\
\text { enterprises; } \\
\text { Technological re- } \\
\text { equipment of canneries; } \\
\text { Creation of high-tech } \\
\text { fast freezing complexes }\end{array}$ \\
\hline $\begin{array}{l}\text { Fish } \\
\text { production } \\
\text { and } \\
\text { processing }\end{array}$ & $\begin{array}{l}\text { Low-tech production; } \\
\text { Shortage of highly } \\
\text { qualified specialists; } \\
\text { Lack of processing } \\
\text { facilities }\end{array}$ & $\begin{array}{l}\text { Underdevelopment of } \\
\text { vertical and horizontal } \\
\text { integration and } \\
\text { cooperation ties between } \\
\text { commodity producers; } \\
\text { Low investment } \\
\text { attractiveness of } \\
\text { business }\end{array}$ & $\begin{array}{l}\text { Restoration of fish } \\
\text { resources and } \\
\text { conservation } \\
\text { management of stocks; } \\
\text { Creation of enterprises } \\
\text { for processing fish raw } \\
\text { materials }\end{array}$ \\
\hline
\end{tabular}

In accordance with the Strategy of Socio-Economic Development of the Southern Federal District for the period up to 2020, the Azov-Don zone of advanced growth was created on the territory of the Rostov Region. Its significance on a federal scale is based on its agricultural and transport potential, which makes it possible to create competitive agricultural clusters.

The newly created interregional agricultural clusters which combine the potential of several territories should enjoy the priority of support from regional authorities. Creating regional institutions for coordinating cluster development will contribute to implementing the strategy. 


\section{Conclusions}

The "Concept of Cluster Development of the Rostov region for 2015-2020" was instrumental in promoting the clustering policy in the region. The analysis of the first achievements of the agro-industrial cluster of the Rostov region (as well as the other five) revealed the limiting factors that hinder the successful implementation of the cluster policy. These limiting factors include:

- the lack of a fully formed cluster infrastructure;

- low efficiency of the existing mechanism for the initialization of the necessary technological developments and the commercialization of the obtained innovations;

- insufficient access to financial resources for the technological re-equipment of the cluster partner enterprises;

- low quality of consulting services in the formation of new cluster structures.

\section{References}

1. Decrease in the RF GDP in 2020 will amount to $3.8 \%$, http://www.finmarket.ru/main/article/5383875

2. U. Cantner, H. Graf, M. Rothgang, Journal of Technology Transfer 44(6), 1665-1672 (2019) doi: 10.1007/s10961-018-9666-4

3. S. Brakman, Ch. van Marrewijk, Cambridge Journal of Regions Economy and Society 6(2), 217-231 (2013) doi: 10.1093/cjres/rst001

4. N. Reid, .D. Gatrell, Spatial Diversity and Dynamics in Resources and Urban Development (Springer Science+Business Media Dordrecht, 2016) doi: 10.1007/978-94017-9786-3_10

5. H. Wolman, D. Hincapie, Economic Development Quarterly 29(2), 135-149 (2015) doi: $10.1177 / 0891242413517136$

6. S. Zemtsov, P. Pavlov, A. Sorokina, Equilibrium-Quarterly Journal of Economics and Economic Policy 11(3), 499-536 (2016) doi: 10.12775/EQUIL.2016.023

7. J. Wilson, International Journal of Business Environment 10(4), 371-382 (2019) doi: 10.1504/IJBE.2019.10023228

8. J.S. Sexton, F. Sanders, Theology and California: Theological Refractions on California's Culture (England, 2014)

9. E. Kozonogova, I. Elokhova, J. Dubrovskaya, N. Goncharova, International Scientific Conference Digital Transformation on Manufacturing, Infrastructure and Service 497 (2018) doi: 10.1088/1757-899X/497/1/012044

10. T. Ignatova, T. Cherkasova, Journal of Economic Regulation 2(10), $72-82$ (2019) doi: $10.17835 / 2078-5429.2019 .10 .2 .072-082$

11. Joint projects of participants of industrial clusters 2018, https://akitrf.ru/upload/Clusters2018.pdf

12. E. Zolochevskaya, T. Cherkasova, O. Mishurina et al., CBU International Conference Proceedings 2018: Innovations in Science and Education, Proceedings of CBU 6, 510515 (2018) doi: 10.12955/cbup.v6.1206

13. Global Economic Summit: A Roadmap for Future Development and Prospects of Clusters, http://globalsummit2014.com/download/ges-report-2013-final.pdf 
14. A. Kowalski, Journal of Competitiveness 12(4), 74-90 (2020) doi: 10.7441/joc.2020.04.05

15. T. Cherkasova, T. Akimova, Scholar notes of Skags 1, 120-126 (2018) 